\title{
Fungsi peran dan teknik komunikasi humas dalam program Sabilulungan Bersih Kabupaten Bandung
}

\author{
Iriana Bakti ${ }^{1}$, Feliza Zubair ${ }^{2}$, Yustikasari ${ }^{3}$ \\ ${ }_{1,2,3}$ Universitas Padjadjaran, Bandung, Indonesia
}

\begin{abstract}
ABSTRAK
Praktik humas pemerintah memegang peranan penting dalam mensosialisasikan kebijakan pemerintah dibidang lingkungan hidup sebagai salah satu koridor pembangunan di Kabupaten Bandung. Praktik ini memperjelas fungsi, peran, dan teknik komunikasinya pada saat menjalankan tugasnya ketika berinteraksi dengan para pemangku kepentingan dalam pelaksanaan kegiatan Sabilulungan Bersih (saber). Penelitian ini bertujuan untuk mengetahui fungsi, peran humas pemerintahan, serta teknik komunikasi yang dilaksanakan dalam melaksanakan kegiatan Sabilulungan Bersih di Kabupaten Bandung. Metode yang digunakan dalam penelitian adalah deskriptif dengan sifat datanya kualitatif. Teknik pengumpulan datanya menggunakan wawancara, observasi, dan studi kepustakaan. Teknik analisis data melalui reduksi data, display data, mencari simpulan, dan verifikasi. Teknik penentuan sumber data didasarkan pada kriteria kemandirian masyarakatnya dalam memahami, mencari solusi atas permasalahan, dan kemampuannya dalam mengelola lingkungan hidup, di mana dari 10 desa yang dilibatkan dalam program Sabilulungan Bersih, ditentukan secara purposif 1 kelurahan, dan 2 desa. Informan dalam penelitian ini adalah aparat pemerintahan kecamatan, kelurahan, dan desa, serta para kader sebanyak 7 orang. Hasil penelitian menunjukkan bahwa fungsi humas pemerintah dalam pelaksanaan program Saber adalah menjadi kepada kepentingan umum, dan memelihara komunikasi yang baik. Peran Humas pemerintahan sebagai fasilitator komunikasi, dan teknisi komunikasi. Komunikasi partisipatif yang terbangun berlangsung secara dialogis yang dilandasi oleh keterbukaan para pesertanya.
\end{abstract}

Kata-kata Kunci: Humas pemerintah; fungsi; peran; komunikasi partisipatif; dialog

\section{Public Relations'role function and communication techniques in The Sabilulungan Bersih Program in Bandung Regency \\ ABSTRACT}

Government public relations play a vital role in disseminating government policies in the environmental sector as one of Bandung Regency's development corridors. This practice clarifies the functions, roles, and communication techniques when carrying out their duties when interacting with stakeholders in Sabilulungan Bersih (Saber) activities. This study aims to determine the function and role of government public relations and communication techniques implemented in carrying out Sabilulungan Bersih activities in the Bandung Regency. The method used in this research is descriptive with qualitative data. Data collection techniques used are interviews, observation, and literature study. The data analysis technique is through data reduction, data display, finding conclusions, and verification. The technique of determining data sources is based on the criteria for the community's independence in understanding, finding solutions to problems, and their ability to manage the environment, where out of ten villages/sub-district involved in the Sabilulungan Bersih program, one sub-district and two villages were purposively determined. The informants in this study were government officials in districts, sub-districts, and villages, as well as seven cadres. The results show that government public relations' function in implementing the Sabilulungan Bersih program served the public interest and maintained good communication. It also shows the role of government Public Relations as a communication facilitator and communication technician. The participatory communication established takes place in a dialogical manner based on the openness of the participants.

Keywords: Government public relations; function; role; participatory communication; dialogue

Korespondensi: Dr. Iriana Bakti, M.Si., Universitas Padjadjaran, Jl. Raya Bandung Sumedang KM.21, Sumedang, Jawa Barat 45363, Email: iriana.bakti@unpad.ac.id 


\section{PENDAHULUAN}

Hubungan masyarakat (humas) merupakan salah satu komponen dalam struktur organisasi pemerintahan yang memiliki peran sangat penting dalam membangun sikap dan partisipasi publik terhadap berbagai persoalan yang terjadi di wilayah garapannya. Salah satu persoalan yang dihadapi adalah masalah lingkungan, khususnya di Kabupaten Bandung berupa penurunan kualitas dan kuantitas lingkungan, Fasilitas Pengelolaan Sampah (FPS) yang kurang, bertambahnya areal lahan kritis, dan lain sebagainya. Kawasan pemukiman, baik berupa perkotaan, maupun pedesaan merupakan tempat tinggal dan tempat beraktivitas yang mendukung perikehidupan dan penghidupan penghuninya (Agustin, 2017).

Untuk mendukung perikehidupan dan penghidupan penghuninya, maka kuantitas dan kualitas lingkungan menjadi kewajiban pemerintah dan masyarakat untuk ditingkatkan, karena khusus di Kabupaten Bandung menurut Asisten Perekonomian dan Kesejahteraan (Ekjah), koridor pembangunan terberat pembangunan Pemerintah Kabupaten Bandung adalah koridor lingkungan hidup, sehingga untuk mengatasi masalah lingkungan ini diperlukan peran dan kerja sama dari berbagai pihak. Masalah lingkungan yang paling menonjol di Kabupaten Bandung adalah sampah, di mana berdasarkan hasil perhitungan dengan menggunakan asumsi produksi sampah $=3$ liter/orang/hari; berat jenis sampah $=0.25$ $\mathrm{kg} / \mathrm{m}$, timbunan sampah di Kabupaten Bandung dengan jumlah penduduk 3.235.615 jiwa sebanyak 2,427 ton/ (Tasrin, 2014).

Volume sampah yang besar ini tidak ditunjang dengan tempat pembuangan sampah yang memadai, sehingga sampah dibuang ke lahan kosong, pinggir jalan, selokan, dan sebagainya, atau dibakar sendiri oleh masyarakat. Realitas ini sangat memprihatinkan karena merusak lingkungan, dan keindahan lingkungan sekitar, serta berpotensi terhadap masalah kesehatan.

Untuk mengatasi masalah lingkungan hidup tersebut Pemkab Bandung telah menerapkan Perda No. 15 Tahun 2012 tentang Pengelolaan Sampah, yang salah satu pasalnya (pasal 9) menjelaskan hak dan kewajiban masyarakat dalam mengelola sampah. Namun demikian, dalam implementasinya menurut Ketua Pusat Sumber Daya Komunitas (PSDK) Daerah Aliran Sungai Citarum (DAS), "kebijakan dalam peraturan tersebut masih lemah, sehingga belum mampu menjawab masalah sampah di Kabupaten Bandung” (Iwank, 2019).

Lemahnya implementasi dari kebijakan Perda di atas, terutama berkaitan dengan kesadaran kerja sama antar pemangku kepentingan. Pada hal ada satu program yang 
dapat mengatasi masalah sampah di Kabupaten Bandung adalah Sabilulungan Bersih. Untuk itu pemerintah Kabupaten Bandung bekerja keras menjalankan Perda tersebut secara masif dan membangun kerja sama dengan berbagai pemangku kepentingan untuk membangun kesadaran bersama dalam rangka menanggulangi permasalahan lingkungan hidup/persampahan di wilayah masing-masing.

Pada dasarnya program Sabilulungan Bersih ini adalah untuk meningkatkan kemandirian masyarakat supaya lebih mandiri dalam memahami permasalahan lingkungan hidup di desa/kecamatannya, sehingga masyarakat mampu mencari solusi atas permasalahan lingkungan, mampu mengelola lingkungan yang berkelanjutan.

Program Sabilulungan Bersih dalam pelaksanaannya di lapangan dilakukan oleh kader lingkungan yang menjadi pelopor berbagai kegiatan lingkungan, membangun swadaya, gotong royong, dan sebagainya, sehingga diperlukan koordinasi, dan komunikasi yang efektif dan efisien yang dapat membangun kesamaan makna tentang lingkungan, membangun sikap, dan partisipasi mereka dalam pengelolaan lingkungan hidup di desa/kecamatannya.

Sabilulungan Bersih menjadi salah satu program yang diharapkan dapat mengatasi masalah lingkungan di Kabupaten Bandung, karena pada umumnya masyarakat masih memiliki kepedulian tentang perilaku hidup bersih, cinta lingkungan, saling berbagi, dan gotong royong. Hal ini merupakan modal sosial yang menjadi sumber daya untuk dimanfaatkan dalam menyelesaikan masalah lingkungan, terutama yang berkaitan dengan masalah persampahan.

Melalui program ini, sampah yang tadinya di anggap sebagai sumber masalah diperlakukan sebagai sumber daya lingkungan untuk dikelola sedemikian rupa, sehingga menjadi sesuatu yang bermanfaat dan menguntungkan dari sisi ekonomi, sosial, dan budaya, yang dalam pengelolaannya disesuaikan dengan kapasitas dan kapabilitas sumber daya di wilayah masingmasing.

Permasalahan yang muncul dalam pelaksanaan program Sabilulungan Bersih di kabupaten Bandung ini, adalah, masih kurangnya koordinasi, dan komunikasi yang efektif dan efisien di antara aparat pemerintah dengan masyarakat, belum terbangun kesamaan makna tentang lingkungan, sikap, dan partisipasi dalam pengelolaan lingkungan hidup di desa-desa. Aparat pemerintah kecamatan, dan kelurahan/desa mengalami kesulitan dalam menerjemahkan bahasa kebijakan ke bahasa teknis yang berkaitan dengan permasalahan tata kelola lingkungan.

Untuk mewujudkan tata kelola lingkungan 
hidup/persampahan, pemerintah Kabupaten Bandung besertajajarandibawahnya(kecamatan dan kelurahan), bekerja sama dengan otoritas di tingkat RT dan RW melakukan berbagai kegiatan penyadaran kepada masyarakat dengan mengutamakan komunikasi partisipatif. Oleh karena itu, komunikasi partisipatif merupakan hak setiap individu yang dapat menjamin terwujudnya kerjasama timbal balik pada seluruh tingkatan partisipasi (Hadiyanto, 2008).

Aktivitas komunikasi yang dilakukan oleh jajaran Pemkab Bandung pada tingkat kecamatan dan kelurahan/desa dengan publik tersebut merupakan implementasi fungsi dan peran humas. Dalam hal ini humas pemerintah berusaha menjangkau publik dengan menyampaikan informasi tentang salah satu koridor kebijakan pembangunan pemerintah Kabupaten Bandung, yaitu pembangunan lingkungan melalui program Sabilulungan Bersih sebagai bentuk pelayanan publik. Hal ini sesuai dengan pendapat sebagai berikut:

"Humas membantu menjangkau publik dengan memberi tahu tentang undangundang, dan program baru, mempromosikan tujuan lembaga melalui sosialisasi layanan publik dengan tujuan untuk mendorong atau mencegah perilaku tertentu, meningkatkan kerja sama pemerintah dengan publiknya melalui berbagai saluran" (Modecai Lee, Grant Neeley, 2012).

Pendapat yaang disampaikan di atas senada dengan tujuan humas pemerintahan adalah:
"Idealnya adalah mengemban misi pemerintah dengan memberi pelayanan kepada publik dengan tidak mengambil keuntungan pribadi, tapi langsung dari operasi pemerintah, karena pemerintah tidak komersial. Walaupun ada persepsi bahwa pelayanan pemerintah tidak sesuai harapan, namun tindakan pejabat dan aparat tidak boleh menutup-nutupi kenyataan ...... Fungsi inti dari semua humas adalah menonjolkan aspek komunikasi pemerintah. Oleh karena itu, dalam setiap tingkatan pemerintah diperlukan petugas humas yang terampil untuk memastikan bahwa informasi yang disampaikan ke publik menjadi jelas, dan efisien" (Cameron, 2011).

Dari kedua pendapat di atas nampak bahwa pada dasarnya, humas pemerintah bertugas melayani publik dengan melakukan aksi komunikasi yang efektif dalam rangka membangun kerja sama di antara kedua belah pihak. Oleh karena itu, walaupun uraian tugas humas pemerintah cukup variatif, namun tetap di sebut sebagai petugas informasi publik (Newsom \& Turk, 2009).

Aktivitas komunikasi yang dilakukan oleh aparat pemerintahan yang berkaitan dengan penyelenggaraan program Sabilulungan Bersih pada dasarnya merupakan implementasi dari fungsi kehumasan pemerintah daerah Kabupaten Bandung yang berupaya memberi penjelasan, dan mengajak masyarakat untuk memanfaatkan berbagai hal yang berkaitan dengan lingkungan hidup/persampahan bisa dikelola menjadi sesuatu yang bermanfaat, seperti jadi pupuk, kerajinan, dll). Untuk itu dalam melaksanakan 
praktik kehumasan pemerintah diperlukan pelayanan informasi yang akurat melalui komunikasi dua arah, sehingga pemerintah dan publiknya dapat bersama-sama membuat kebijakan publik (Idris, 2015).

Praktik humas pemerintah Kabupaten Bandung yang terjadi pada tataran kecamatan dan kelurahan/desa dalam pelaksanaan program Sabilulungan Bersih ini, sesuai dengan fungsi humas, yaitu mengabdi kepada kepentingan umum, dan memelihara komunikasi yang baik (Canfield, 2002).

Fungsi humas tersebut dijalankan oleh humas Pemkab Bandung dengan tujuan untuk membangun kesadaran publik dalam pengelolaan lingkungan hidup/persampahan di wilayahnya masing-masing, dengan memanfaatkan teknik komunikasi tertantu. Fokus pada tujuan dari humas pemerintah ini sangat membantu karena begitu tujuan tertentu telah diidentifikasi, teknik komunikasi khusus yang digunakan untuk mencapai tujuan tersebut akan mengalir secara alami (Modecai Lee, Grant Neeley, 2012).

Hasil penelitian terdahulu tentang humas pemerintah menunjukkan bahwa pelayanan informasi yang akurat melalui komuniksi dua arah, antara pemerintah dan publiknya dapat membuat kebijakan publik (Idris, 2015). Kunci akuntabilitas pemerintah yang dapat meningkatkan kinerja pemerintah dibangun melalui penyampaian informasi dalam komunikasi eksternal (Lee \& Neeley, 2012). Praktik kehumasan yang profesional dan proporsional memiliki kontribusi dalam mendukung tugas aparatur (Kasmirus, 2013). Keterbukaan dalam berkomunikasi terbentuk oleh kemampuan menjadi pendengar, penghubung, dan penerjemah antara instansi dengan publiknya (Siswanto \& Abraham, 2016).

Hasil Penelitian terdahulu tentang komunikasi partisipatif menunjukkan bahwa Komunikasi partisipatif memiliki ciri khas berupa dialog dimana pengirim (sender) dan penerima (receiver) pesan saling berinteraksi untuk bertukar informasi (Syarah et al., 2017). Kekuatan dialog sebagai proses komunikasi yang intensif dan berkesinambungan dapat menjadi solusi untuk mencapai kemajuan bersama dengan mengatasi berbagai hambatan (Wahyono, 2018).

Kegiatan kehumasan pemerintah Kabupaten Bandung melalui berbagai aktivitas komunikasinya mempertegas peran dari humas itu sendiri, di mana peran humas tersebut dapat dikategorikan sebagai: "Expert Presciber (Penasihat Ahli) dalam rangka membantu menyelesaikan permasalahan relasi dengan publik. Communication facilitator (Fasilitator Komunikasi) dalam rangka membantu manajemen memantau keinginan dan harapan 
publik. Problem Sloving Process Fasilitator (Fasilitator Proses Pemecahan Masalah) dalam rangka memberi nasehat kepada pimpinan dan mengambil tindakan secara rasional dan profesional unjtuk mengatasi persoalan yang dihadapi. Communication Technician ( Teknisi Komunikasi) dalam rangka memberi layanan komunikasi secara teknis yang berkaitan dengan arus komunikasi dan media yang digunakan sesuai dengan strukturnya" (Dozier, Broom, 2000).

Teknik komunikasi yang dilakukan dalam menjalankan fungsi humas pemerintah Kabupaten Bandung adalah komunikasi partisipatif, di mana dalam praktiknya, masyarakat diberi kesempatan untuk menyampaikan gagasannya, sehingga dalam proses pengambilan keputusan untuk melakukan pengelolaan persampahan dilakukan bersama pemerintah dan masyarakat.

Sementara itu, dalam komunikasi partisipatif harus dipahami bahwa: a) masyarakat adalah aktor yang dinamis, aktif terlibat dalam proses perubahan sosial dan turut mengendalikan cara-cara komunikasi dan isi komunikasi, alih-alih sebagai penerima informasi dan petunjuk-petunjuk berperilaku yang pasif, sementara orang lain yang membuat keputusan kehidupan mereka. b) Proses komunikasi disesuaikan dengan komunitas atau kelompok sosial tertentu, baik menyangkut isi, bahasa, budaya maupun media yang digunakan.

c) Dialog yang dilakukan berbasis komunitas dan cara-cara komunikasi. d) Proses komunikasi merupakan "hak rakyat" yang ditujukan untuk membantu mengidentifikasi, mendefinisikan perbedaan antara felt needs dan real needs dimiliki untuk memberikan kesempatan yang sama pada komunitas. e) Proses untuk mencapai penyadaran dan pemahaman yang mendalam tentang realitas sosial, masalah serta solusinya" (Servaes, 2002).

Konsep komunikasi partisipatif terdiri dari, Heteroglasia, kelompok dan komunitas yang berbeda-beda dengan berbagai variasi ekonomi, sosial, dan faktor budaya yang saling mengisi satu sama lain melandasi sistem pembangunan. Dialog, terjadi ketika pengirim (sender) dan penerima (receiver) pesan saling berinteraksi dalam suatu periode waktu tertentu sampai pada makna-makna yang saling berbagi, ini merupakan aktivitas komunikasi transaksional. Poliponi, terjadi ketika suara-suara yang tidak menyatu atau terpisah meningkat menjadi terbuka, memperjelas, dan tidak menutupi satu sama lain. Ini merupakan bentuk ideal dari dialog. Karnaval, biasa dilakukan dengan tidak formal diselingi oleh humor dan canda tawa, yang bagi komunikasi pembangunan diwujudkan melalui berbagai ritual seperti legenda, komik, festival, permainan, parodi, dan hiburan secara bersama- sama (Rahim, 2004). 
Penelitian ini bertujuan untuk mengetahui fungsi dan peran humas pemerintahan, serta teknik komunikasi yang dilaksanakan dalam melaksanakan kegiatan Sabilulungan Bersih di Kabupaten Bandung.

\section{METODE PENELITIAN}

Jenis penelitian yang dilakukan dalam penelitian ini adalah kualitatif dengan menggunakan metode deskriptif untuk menggambarkan fenomena yang berkaitan dengan aktivitas kehumasan Pemkab Bandung dalam mengelola masalah lingkungan hidup/ persampahan melalui program Sabilulungan Bersih di beberapa kecamatan yang ada di Kabupaten Bandung.

Teknik pengumpulan data yang dilakukan untuk memperoleh data yang dibutuhkan, penulis melaksanakan observasi secara sistematis dengan mengamati, dan mencatat aktivitas yang dilakukan para nara sumber pada saat melaksanakan aktivitas komunikasinya, baik pada saat ada forum pertemuan, maupun pada saat melakukan aktivitas pengelolaan lingkungan, dan melakukan wawancara secara mendalam guna mendapatkan data tentang peran kehumasan Pemkab Bandung, dan teknik komunikasi yang diakukan dalam mengelola lingkungan hidup/persampahan di beberapa kecamatan di wilayah Kabupaten Bandung. Setelah itu dilakukan studi dokumentasi/ kepustakaan yang berkaitan dengan konsep yang berkaitan dengan peran humas pemerintahan dan teknik komunikasi dalam mengelola lingkungan hidup/persampahan.

Teknik analisis data yang digunakan dalam penelitian ini terdiri dari Reduksi data, dimana data yang berkaitan dengan fungsi dan peran humas, serta aktivitas komunikasi partisipatif di merangkum, dipilih hal-hal yang pokok, difokuskan pada hal-hal yang penting, dan dicari tema atau polanya sehingga mudah diproses. Display data. Agar dapat melihat gambaran keseluruhan atau bagianbagian tertentu dari penelitian yang berkaitan dengan fungsi dan peran humas, serta aktivitas komunikasi partisipatif yang terjadi dengan yang tergambarkan dalam tabel penelitian. Mengambil simpulan dan verifikasi, peneliti berusaha untuk mencari makna data yang dikumpulkannya. Untuk itu dicari pola, tema, hubungan, persamaan, hal-hal yang sering timbul, dan sebagainya dalam rangka mencari kesimpulan tentang Praktik humas pemerintah, kemudian mencari data baru, untuk mencapai inter-subjective consensus, yakni persetujuan bersama agar lebih menjamin validitas atau confirmability.

Penentuan sumber data dalam penelitian ini didasarkan pada kriteria kemandirian masyarakatnya dalam memahami, mencari solusi atas permasalahan, dan kemampuannya 
dalam mengelola lingkungan hidup, di mana dari 10 desa yang dilibatkan dalam program Sabilulungan Bersih, ditentukan secara purposif 3 wilayah, terdiri dari 1) Kelurahan Rancaekek Kulon, 2) Desa Margahurip di Kecamatan Banjaran, dan 3) Desa Rancaekek Kulon di Kecamatan Rancaekek, dan Desa Tenjolaya di Kecamatan Cicalengka.

Adapun subjek penelitian yang dijadikan nara sumber dalam penelitian ini adalah aparat pemerintahan kecamatan dan desa yang, serta para kader yang ditugaskan melaksanakan komunikasi dengan masyarakat dalam mengelola lingkungan hidup/persampahan sebagai implementasi dari program Sabilulungan Bersih sebanyak 7 orang. Penentuan informan/ nara sumber tersebut didasarkan pada kesediaannya menerima kehadiran peneliti untuk diwawancarai, dan mampu mengutarakan pengalamannya selama aktif dalam kegiatan Sabilulungan Bersih, dan memiliki sesuatu yang menarik pengalaman khusus mengelola sampah yang sebelumnya merupakan sumber masalah lingkungan, menjadi sumber daya lingkungan.

Untuk mengetahui validitas data dalam penelitian ini, peneliti melakukan triangulasi sumber dengan mengkonfirmasikan data yang diperoleh dari wawancara dan observasi mengenai aktivitas kehumasan dan teknik komunikasi yang terjadi dalam pengelolaan lingkungan hidup/persampahan.
Teknik analisis data dalam penelitian ini dilakukan dengan cara mereduksi data, di mana data hasil observasi dan wawancara tentang aktivitas kehumasan dan teknik komunikasi yang terjadi dalam pengelolaan lingkungan hidup/ persampahan direduksi, dirangkum, dipilih hal-hal yang pokok, difokuskan pada hal-hal yang penting, dicari tema atau polanya sehingga mudah diproses. Display data untuk melihat gambaran keseluruhan atau bagian-bagian tertentu dari aktivitas kehumasan dan teknik komunikasi yang terjadi dalam pengelolaan lingkungan hidup/persampahan, sehingga dapat diverifikasi oleh peneliti. Mengambil kesimpulan, di mana peneliti berusaha untuk mencari dan mengumpulkan dan menjelaskan aktivitas kehumasan dan teknik komunikasi yang terjadi dalam pengelolaan lingkungan hidup/persampahan dengan mencari pola, tema, hubungan, persamaan, hal-hal yang sering timbul, dan sebagainya dalam rangka mencari kesimpulan.

\section{HASIL DAN PEMBAHASAN}

Proses pelaksanaan kebijakan yang melibatkan publik dalam kaitannya dengan program Sabilulungan Bersih, aparat Pemerintah Kabupaten Bandung, khususnya aparat dari tingkat kecamatan dan kelurahan/desa terlebih dahulu mengundang beberapa tokoh publik kunci yang menjadi pemuka pendapat di 
setiap wilayah kecamatan diberi informasi yang berkaitan dengan program tersebut, mulai dari kebijakan pembuatan program, pengertian, perencanaan, dan pelaksanaannya, yang menurut Pak Aden, Kasi Pemberdayaan

Kecamatan Banjaran:

"Tujuan dilaksanakan Sabilulungan Bersih adalah mengubah "mindset" masyarakat tentang kebersihan lingkungan dan pengelolaan sampah, sehingga sampah bisa berguna dan menjadi pendapatan; sampah bukan masalah (bisa jadi pupuk, dll). Oleh karena itu, pemerintah sangat berkepentinganmenginformasikan program ini kepada masyarakat, dan juga pemerintah akan membantu dalam pelaksanaannya di lapangan. Jadi pemerintah akan terus menjalin komunikasi”.

Praktik humas pemerintah di Kecamatan Banjaran ini berlangsung dengan memanfaatkan sarana komunikasi yang disebut dengan Forum Komunikasi Kecamatan Sehat (FKKS). Dalam hal ini, pihak kecamatan melakukan upaya menyukseskan salah satu kebijakan Pemkab di bidang lingkungan hidup/persampahan dengan men-desiminasikan informasi seputar kebijakan program Sabilulungan Bersih, adapun teknik pelaksanaan di lapangan diserahkan kepada masyarakat, yang kemudian direspons oleh masyarakat yang tergabung dalam Kelompok Wanita Tani dan PKK dengan program unggulannya Kawasan Rumah Pangan Lestari (KRPL) dan bank Sampah.

Praktik humas pemerintahan dalam program Sabilulungan Bersih di lingkungan di Kecamatan Rancaekek dapat dilihat dari tindakan komunikasi yang dilakukan oleh Yulianto, Sekretaris kecamatan:

"Program Sabilulungan Bersih telah disosialisasikan sejak dua tahun yang lalu, di mana pada waktu itu, Pemerintah kecamatan Rancaekek menyampaikan informasi Saber kepada para tokoh masyarakat, yang dihadiri Lurah/Kepala Desa, dan perangkatnya, Ketua RW, ketua RW, dan undangan lainnya. Pada sosialisasi tersebut, Kami menyampaikan berbagai informasi tentang program saber untuk membangun kesadaran masyarakat dalam memelihara lingkungan hidup terutama berkaitan dengan masalah sampah".

Pelaksanaan Sabilulungan Bersih di kecamatan Rancaekek untuk selanjutnya pemantauannya diserahkan kepada Lurah/ Kepala Desa, yang secara struktural interaksinya dengan masyarakat lebih mudah, selain itu di pantau juga oleh pihak RW dan RT, yang langsung berinteraksi dengan masyarakat.

Praktik pemantauan seperti ini merupakan hal yang lumrah dalam struktur birokrasi pemerintahan, di mana secara struktural birokrasi pemerintahan daerah, kelurahan/desa menjadi ujung tombaknya, sehingga kegiatan pertemuan Saber di Kecamatan Rancaekek, lebih sering dilakukan di kelurahan/desa.

Program Sabilulungan Bersih di Kecamatan Rancaekek kemudian salah satunya direspon oleh masyarakat yang tergabung dalam komunitas Sailulungan Bersih Kencana dan KWT Kencana Lestari di Kelurahan Rancaekek Kulon. 
Sementara itu Praktik humas pemerintah dalam pelaksanaan program Sabilulungan Bersih dilakukan di kecamatan Cicalengka, di mana menurut Yuli Hastuti, Kasi Sosial Budaya: "Untuk menunjang pelaksanaan program Sabilulungan Bersih di Kecamatan Cicalengka, pihak kecamatan menyelenggarakan rapat koordinasi dengan mengundang para kepala desa, tokoh masyarakat, tokoh agama, tokoh pemuda, dan undangan lainnya. Saya memberi gambaran umum kebijakan program Sabilulungan Bersih sebagai program Pemkab Bandung untuk dilaksanakan di wilayah ini, sehingga masyarakat menjadi paham. Adapun untuk teknis penyelenggaraannya diserahkan kepada para kepala desa, pihak kecamatan akan memfasilitasi kebutuhan, dan melakukan pemantauan dalam pelaksanaannya".

\section{Berdasarkan wawancara dengan} narasumber, ternyata Praktik kehumasan yang dilakukan oleh aparat pada tingkat kecamatan dalam pelaksanaan program Sabilulungan Bersih di Kabupaten Bandung dilihat dari fungsi dan perannya dapat dilihat pada tabel 1.

Praktik kehumasan yang dilaksanakan oleh beberapa kecamatan yang ada di dalam struktur Pemkab Bandung telah menunjukkan fungsi kehumasan sesuai dengan situasi, kondisi wilayahnya, serta kapasitas kerja aparat sesuai dengan tugasnya dalam mensukseskan program Sabilulungan Bersih di wilayahnya. Para aparat kecamatan dan kelurahan, desa berkomitmen dalam mendukung program Saber di kabupaten Bandung, karena harus mengamankan kebijakan atasannya (Bupati) di bidang penataan lingkungan hidup/persampahan sebagai salah satu koridor pembangunan di kabupaten Bandung. Komitmen aparat memiliki pengaruh yang signifikan terhadap kinerjanya (Salwa, Away, \& Tabrani, 2018) integritas dan kompetensi terhadap kinerja Komisi Independen Pemilihan (KIP).

Praktik kehumasan pemerintah dalam program Sabilulungan Bersih ini, selain dilakukan oleh pihak kecamatan, juga oleh

Tabel 1 Fungsi Dan Peran Humas Pemerintah Dalam Program Sabilulungan Bersih

\begin{tabular}{llll}
\hline Praktik Kehumasan & Kec. Banjaran & Kec. Rancaekek & Kec. Cicalengka \\
\hline Fungsi & Menjalin & Membangun & Membangun pemahaman \\
& komunikasi & kesadaran & \\
Peran & Memberi informasi & Memberi & Memberi informasi dan \\
& dan fasilitas & informasi dan & fasilitas, dan memantau \\
& & fasilitas & \\
\hline
\end{tabular}


pihak kelurahan/desa, sebagai ujung tombak dalam berinteraksi dengan masyarakat. Arus komunikasi berdasarkan struktur birokrasi pemerintahaninimerupakan hal yangbiasa untuk menghindari kesalahpahaman pemahaman, menghindari tumpang tindih dalam tugas, dan membangun koordinasi di antara aparat tentang program Saber. Oleh karena itu, komunikasi organisasi ini harus dipahami selain sebagai tindakan kelembagaan (state of being), juga harus dipahami sebagai metode komunikasi (method of communication), karena dalam praktiknya menunjukkan fungsi dan pendekatan kehumasan (Ishak, 2012).

Aktivitas komunikasi di antara aparat pemerintahan sendiri, dan diantara aparat dengan masyarakat merupakan suatu aksi layanan publik yang sangat penting dilaksanakan oleh humas pemerintahan dalam mewujudkan program Sabilulungan Bersih di kabupaten Bandung. Penyampaian informasi kepada publik merupakan kegiatan komunikasi eksternal yang menjadi kunci akuntabilitas pemerintah yang dapat meningkatkan kinerja pemerintah (Lee \& Neeley, 2012). Dengan demikian, Praktik kehumasan yang profesional dan proporsional memiliki kontribusi dalam mendukung tugas aparatur (Kasmirus, 2013).

Aktivitas komunikasi dalam pelaksanaan program Sabilulungan Bersih berlangsung dua arah/timbal balik. Ini menunjukkan bahwa arus komunikasinya berlangsung secara bottom up, artinya pihak aparat tidak mendominasi pembicaraan program, tetapi juga mendengar dan mengakomodasi berbagai pendapat dari masyarakat. Oleh karena itu pada tataran aplikasinya, program Sabilulungan Bersih di Kabupaten Bandung bentuk kegiatan, dan implementasi kegiatannya diputuskan secara demokratis yang berbasis masyarakat. Kemampuan menjadi pendengar, penghubung, dan penerjemah antara instansi dengan publiknya merupakan bentuk keterbukaan dalam berkomunikasi (Siswanto \& Abraham, 2016).

Praktik kehumasan yang dilakukan oleh aparat kecamatan dan kelurahan/desa dalam pelaksanaan program Sabilulungan Bersih di Kabupaten Bandung pada dasarnya merupakan implementasi dari fungsi dan peran humas pemerintahan itu sendiri, yang menurut Bertrand R. Canfield, diantaranya adalah mengabdi kepada kepentingan umum, dan memelihara komunikasi yang baik (Ardianto, 2013), sehingga humas pemerintahan tersebut dapat membantu aparat, departemen, dan entitas publik lainnya menjalankan fungsi manajemen untuk merespon masyarakat yang dilayaninya (Cutlip \& Allen, 2009).

Fungsi Praktik humas pemerintahan yang dilakukan aparat kecamatan dan kelurahan/desa dalam mendukung dan mengamankan kebijakan 
pemerintah di bidang lingkungan merupakan upaya menjalin komunikasi, membangun pemahaman, dan kesadaran masyarakat tentang pengelolaan lingkungan hidup/persampahan di wilayah masing-masing. Komunikasi yang dilaksanakan secara terus-menerus oleh aparat dengan masyarakat dapat menimbulkan kesadaran dan partisipasi masyarakat dalam membangun daerahnya (Sari \& Basit, 2018).

Menjalin komunikasi dengan berbagai publik merupakan salah satu fungsi humas yang fundamental dalam Praktik humas pemerintahan yang dilaksanakan aparat kecamatan dan kelurahan/desa dalam pelaksanaan program Sabilulungan Bersih di Kabupaten Bandung, karena dengan komunikasi, kebijakan pemerintah dapat disosialisasikan, opini publik dapat disalurkan. Oleh karena itu, fungsi humas pemerintah menjadi penting untuk mengkomunikasikan berbagai rencana kerja, kinerja, dan pencapaian hasil yang dilakukan pemerintah kepada publik, serta merespons aspirasi publik (Multi et al., 2019). Untuk itu, humas pemerintah harus profesional dalam melayani informasi publik, dan menjalin hubungan dengan publik dalam mendorong partisipasi publik (Sani, 2014).

Fungsi humas pemerintahan di Kabupaten Bandung menunjukkan adanya perubahan mendasar, yang semula bertugas mengelola informasi dan komunikasi, dengan adanya program Sabilulungan Bersih, fungsi humas menjadi sarana diskusi/bertukar pikiran di antara aparat dengan warganya, sehingga aspirasi masyarakat dapat tersalurkan, dan pengambilan keputusan dapat dilakukan bersama. Oleh karena itu, kelembagaan humas pemerintah secara fungsional dan operasional menjadi strategis terutama yang berkaitan dengan penyebarluasan informasi secara terbuka tentang kegiatan instansi, penerjemahan kebijakan pemerintah, dan sebagainya. Kondusifitas iklim komunikasi yang terbangun melalui keterbukaan komunikasi dapat menimbulkan kepercayaan, kedekatan, dukungan, dan kesediaan untuk mendengarkan berbagai problematika yang dilandasi oleh kesediaan untuk menerima kekurangan dan kelebihan masing-masing (Suparna, Rachmawati, \& Winoto, 2013).

Fungsi humas pemerintahan yang dilaksanakan oleh aparat kecamatan dan kelurahan/desa dalam kaitannya dengan program Sabilulungan Bersih adalah mengabdi kepada kepentingan umum dan memelihara komunikasi yang baik. Pengabdian kepada kepentingan umum dilakukan oleh aparat pemerintah kecamatan dan kelurahan tidak terlepas dari aksi komunikasi yang secara intensif dilaksanakan. Memelihara komunikasi dengan tujuan membangun pemahaman, dan kesadaran masyarakat merupakan bentuk pengabdian kepada kepentingan umum, 
sebaliknya untuk menunjukkan pengabdiannya kepada kepentingan umum, salah satunya harus melakukan dan memelihara komunikasi, sehingga Komitmen aparat memiliki pengaruh yang signifikan terhadap kinerjanya (Multi et al., 2019).

Praktik kehumasan pemerintah dalam pelaksanaan program Sabilulungan Bersih di Kabupaten Bandung, selain telah menunjukkan fungsinya, yaitu memelihara komunikasi yang baik dengan berbagai pemangku kepentingan, dan mengabdi kepada kepentingan umum dalam rangka membangun pemahaman dan kesadaran tentang pengelolaan lingkungan hidup, humas pemerintahan kecamatan dan kelurahan/desa juga telah menunjukkan perannya.

Peran sendiri merupakan suatu aktivitas yang dilakukan seseorang sesuai dengan kedudukannya dalam sebuah lembaga/instansi. Peran aparat kecamatan dan kelurahan/ desa dalam kaitannya dengan program Sabilulungan Bersih di kabupaten Bandung adalah menyampaikan informasi, menyediakan fasilitas, dan memantau implementasi program Sabilulungan Bersih yang dilakukan oleh masyarakat di wilayahnya masing-masing, yang kemudian dalam implementasi kegiatannya diputuskan secara demokratis. Dengan demikian, selain sebagai alat propaganda pemerintah dan pelayanan informasi, Praktik kehumasan juga dapat berperan sebagai agen demokrasi dengan menampung berbagai umpan balik dari publik (Idris, 2015).

Salah satu peran yang dilaksanakan oleh aparat pemerintah kecamatan dan kelurahan/ desa dalam pelaksanaan program Sabilulungan Bersih adalah menyampaikan informasi kepada pemangku kepentingan, dalam hal ini adalah para kader, tokoh agama, dan anggota masyarakat lainnya. Menyebarluaskan informasi tentang kebijakan pemerintah kepada masyarakat merupakan tugas pokok humas pemerintah dalam mengamankan kebijakan pemerintah (Ruslan, 2014). Kebijakan Pemkab Bandung salah satunya adalah pembangunan lingkungan hidup yang diimplementasikan dalam program Sabilulungan Bersih.

Praktik kehumasan yang berlangsung dalam pelaksanaan program Sabilulungan Bersih di Kabupaten Bandung dalam tataran implementasinya lebih kepada teknik komunikasi, karena tidak langsung dilakukan oleh bagian humasnya, tetapi oleh aparat pada tingkat kecamatan, dan desa/kelurahan, yang secara fungsi lebih kepada pengabdian kepada kepentingan umum dengan memelihara komunikasi yang baik.

Selain itu, peran kehumasan dalam pelaksanaan program Saber ini lebih kepada teknik komunikasi berupa diseminasi informasi tentang program Sabilulungan Bersih, dan fasilitator komunikasi dengan menyediakan 
berbagai informasi yang terkait dengan pelaksanaan Saber. Oleh karena itu, sebagai perantara komunikasi pemerintah dengan publiknya, maka interaktivitas pelayanan informasi oleh humas menjadi penting (Siswanto \&Abraham, 2016). Peran sebagai fasilitator juga melaksanakan pemantauan proses pelaksanaan pembangunan dan pendampingan kepada masyarakat, dan melakukan evaluasi program bersama masyarakat untuk bahan pelaporan kegiatan (Agustin, 2017).

Program Sabilulungan Bersih yang dilaksanakan di Kabupaten Bandung bisa terlaksana karena faktor komunikasi yang intensif dan efektif. Dikatakan intensif, karena di antara para pelakunya, baik pihak pemerintah, maupun masyarakat sering berkomunikasi secara dialogis pada pertemuan desa atau kunjungan ke lokasi. Dikatakan efektif, karena terjadi perubahan sikap dan perilaku dalam pengelolaan lingkungan/persampahan di wilayahnya. Hal ini sesuai dengan tandatanda komunikasi yang efektif, yaitu dapat menimbulkan pengertian, kesenangan, pengaruh pada sikap, hubungan yang baik, dan tindakan (Tubbs, Stewart \& Moss, 2008).

Komunikasi yang berlangsung dalam pelaksanaan program Sabilulngan Bersih merupakan Praktik komunikasi partisipatif. Hal ini bisa dilihat dari hasil wawancara dengan para informan sebagai berikut:
MenurutBendahara Kampung Sabilulungan

Bersih:

"kami melakukan komunikasi rutin sebulan sekali di forum Kelompok Wanita Tani untuk membahas berbagai masalah lingkungan, seperti sampah dan pemanfaatan lahan diperkarangan. Untuk sampah di kelola oleh Bank Sampah, untuk penghijauan dikelola oleh Kelompok Wanita Tani. Pokoknya, dalam forum itu urun rembug dengan masyarakat dan ada kesepakatan, saling mendukung, dan kerja sama".

Hal senada disampaikan juga oleh Ketua

Bank Sampah:

"Kalau berkomunikasi sama anggota ada waktu untuk pertemuan, menyampaikan informasi, dan menampung informasi. Jadi gimana caranya kita untuk menjalankan kegiatan ini atau misalkan ada hal yang baru atau ada perencanaan yang mau di dikerjakan, jadi ada dialog dialog dulu agar semua paham, seneng, yakin, dan mau ngerjakan".

Komunikasi partispatif yang terbangun dalam pelaksanaan Saber di Desa Margahurip Kecamatan banjaran tersebut ini membuahkan hasil terpilihnya Bank Sampah Dahlia menjadi yang terbaik se-Kabupaten Bandung.

Sementara itu aktivitas komunikasi partisipatif di Kecamatan Rancaekek dinyatakan oleh Ketua Wanita Tani Kelurahan Rancaekek Kencana, bahwa:

"Pembinaan kepada anggota Saber tentang lingkungan, sampah, penanaman pohon dll. Beberapa program "berat" disampaikan secara sederhana agar mudah dipahami, kami dibantu fasilitator kecamatan diskusi untuk menentukan program, semua pendapat ditampung dan banyak yang diterima, karena sesuai dengan kebutuhan". 
Kegiatan Sabilulungan Bersih di Kelurahan Rancaekek Kencana ini membuahkan hasil menjadi proyek percontohan Penataan Lingkungan Berbasis masyarakat Menuju Wilayah Green \& Clean, berupa penyusunan kapling tanaman oleh kelompok Wanita Tani, pembuatan ecobrik menjadi kursi dan lainlain, serta budidaya mangot hasil daur ulang sampah. Aktivitas komunikasi partisipatif juga terjadi pada pelaksanaan Sabilulngan Bersih di Desa Nagrog Kecamatan Cicalengka, di mana menurut Kasi Kasi Budaya kecamatan Cicalengka:

"Di Kampung nagrog terdapat musyawarah dusun sebagai forum masyarakat desa untuk mewujudkan partisipasinya dalam pembangunan desa, semua usulan dari masyarakat disampaikan, bahkan dalam setiap riungan di Nagrog kesadaran masyarakatnya sudah tumbuh selama ini sampai riungan ke delapan itu insyaalloh lah gak ada masalah".

Pelaksanaan Sabilulungan Bersih di Desa Nagrog Kecamatan Cicalengka, yang basisnya konservasi, yang dalam implementasinya dengan menerapkan kegiatan yang disebut "pohon kelahiran”, kalau ada yang melahirkan, sebelum minta surat keterangan lahir dari desa, diwajibkan menanam 2 pohon. Desa Nagrog pada tahun 2018, berhasil menjadi yang terbaik pada lomba desa tingkat provinsi Jawa Barat, dan tahun 2019 menjadi juara Lomba Desa tingkat Nasional.

Berdasarkan wawancara dengan informan aktivitas komunikasi partisipatif dalam pelaksaan program Sabilulungan bersih pada beberapa kelurahan/desa di Kabupaten Bandung dapat dilihat pada tabel 2.

Kegiatan Sabilulungan Bersih di Kabupaten Bandung memerlukan partisipasi aktif masyarakat. Oleh karena itu pemerintah kabupaten berusaha menerapkan program ini dengan mengajak, memotivasi, memediasi, memfasilitasi, dan mengedukasi masyarakat untuk mengatasi masalah lingkungan sebagai salah satu koridor pembangunan di Kabupaten

Tabel 2 Komunikasi Partisdipatif Dalam Program Sabilulungan Bersih

\begin{tabular}{llll}
\hline Komunikasi Partisipatif & Kec. Banjaran & Kec. Rancaekek & Kec. Cicalengka \\
\hline Dialog & Urun rembug, sharing & Diskusi & Musyawarah \\
& informasi & & \\
Poliponi & kesekapakatan, saling & Menampung pendapat & Kesadaran \\
& mendukung, dan kerja & \\
& sama & \\
\hline
\end{tabular}

Sumber: Hasil penelitian Implementasi Komunikasi Lingkungan Melalui Kampung Sabilulungan Bersih Di kabupaten Bandung, 2019 
Bandung. Untuk membangun partisipasi tersebut, diperlukan komunikasi partisipatif yang intensif dan efektif. Melalui pendekatan komunikasi partisipatif gairah masyarakat akan bangkit untuk memikirkan kebutuhannya, sehingga program yang dibentuknya mendapat dukungan dan persetujuan pemerintah. Hal ini menjadi angin segar untuk pemberdayaan masyarakat (Muchtar, 2016).

Komunikasi partisipatif dalam kegiatan Sabilulungan Bersih di Kabupaten Bandung secara umum berlangsung secara dialogis dalam sebuah forum pertemuan dalam musyawarah desa, kantor sekretariat kampung saber, dan sebagainya. Pada forum pertemuan tersebut, terjadi interaksi dari berbagai pemangku kepentingan dari kecamatan kelurahan/desa, dan instansi terkait lainnya dengan masyarakat yang menjadi subjek dalam pelaksanaan program saber tersebut. Dialog ini merupakan ciri khas dari komunikasi partisipatori, dimana pengirim (sender) dan penerima (receiver) pesan saling berinteraksi untuk bertukar informasi (Syarah et al., 2017). Oleh karena itu, kekuatan dialog sebagai proses komunikasi yang intensif dan berkesinambungan dapat menjadi solusi untuk mencapai kemajuan bersama dengan mengatasi berbagai hambatan (Wahyono, 2018).

Dialog menjadi fondasi yang kokoh dalam membangun kesepahaman dan partisipasi masyarakat dalam pelaksanaan program
Saber di Kabupaten Bandung. Dalam dialog tersebut, pihak pemerintah tidak mendominasi komunikasi dalam setiap pembicaraan, melainkan mendengar dan menerima aspirasi masyarakat yang berkaitan dengan pelaksanaan Sabilulungan Bersih di wilayahnya. Masyarakat diberi keleluasaan untuk menyampaikan ide-ide dan saran sesuai kebutuhan yang selaras dengan program, sehingga dalam implementasinya dapat melaksanakan program Sabilulungan Bersih tersebut secara mandiri, dan mendapat dukungan dari pemerintah. Komunikasi akar rumput yang dibumbui oleh kebijakan dan intervensi pemerintah ini membangkitkan kegairahan masyarakat, dan ini merupakan bentuk komunikasi partisipatif berupa kegiatan masyarakat yang didukung pemerintah, bukan kegiatan pemerintah yang dilaksanakan masyarakat (Muchtar, 2016).

Program Sabilulungan Bersih yang dilaksanakan oleh Pemkab Bandung ini merupakan program pemberdayaan berbasis masyarakat, karena implementasi di lapangan berasal dari gagasan masyarakat yang kemudian mendapat dukungan dari pemerintah, sehingga terbangun kemandirian masyarakat untuk mengelola lingkungan/persampahan di wilayahnya. Gagasan masyarakat yang didukung pemerintah ini merupakan manifestasi dari kemitraan diantara kedua belah pihak dalam rangka mencapai tujuan 
bersama yaitu menciptakan lingkungan hidup yang baik. Kemitraan yang terbangun dengan mengkolaborasikan kedua sumber daya tersebut dapat memberikan hasil yang optimal, karena aktor-aktor yang terlibat dalam pemberdayaan tersebut memiliki tujuan yang sama (Hayati, 2017).

Berdasarkan kemandirian yang dimiliki masyarakat tersebut, membuahkan hasil berupa prestasi yang membanggakan bagi kelurahan/ desa, seperti Bank Sampah terbaik tingkat kabepaten, menjadi proyek percontohan Penataan Lingkungan Berbasis masyarakat Menuju Wilayah Green \& Clean, dan menjadi yang terbaik pada lomba desa tingkat provinsi Jawa Barat, serta menjadi juara Lomba Desa tingkat Nasional. Prestasi yang diperoleh setiap kecamatan/desa di atas tidak mudah diraih begitu saja, dalam perjalanan waktunya, komunikasi terus dijalin sejak mulai dari perencanaan, pelaksanaan, dan evaluasi program. Komunikasi dalam pelaksanaan program Sabilulungan Bersih di Kabupaten Bandung rutin dilaksanakan yang dibimbing/ dipandu oleh fasilitator, dan berlangsung dialogis berupa urun rembug, berbagi informasi, diskusi, dan musyawarah untuk mencapai mufakat tentang program pengelolaan lingkungan/persampahan yang akan dilaksanakan sesuai potensi yang dimiliki oleh wilayahnya masing-masing. Pertemuan rutin yang dibimbing oleh fasilitator ini merupakan komunikasi partisipatif yang menyebabkan pesertanya menjadi aktif berdialog, sehingga berdampak pada perasaan puas, dan bangga atas kontribusinya pada peningkatan kualitas lingkungan, dan pengembangan kewirausahaan (Sutowo, 2020).

Para peserta komunikasi partisipatif dalam pelaksanaan Sabilulungan Bersih di Kabupaten Bandung telah menunjukkan kebersamaan, dan kesetaraan dalam berkomunikasinya, sehingga mereka yang terlibat di dalamnya memiliki hak untuk berpartisipasi, baik dalam proses pembuatan keputusan, perencanaan, pelaksanaan, dan evaluasi kegiatan. Hak berpartisipasi ini dapat mewujudkan kerja sama timbal balik pada seluruh tingkatan partisipasi yang didasarkan pada kemitraan dan semangat untuk saling berbagi (Hadiyanto, 2008).

Program Sabilulungan Bersih yang dilaksanakan di Kabupaten Bandung pada dasarnya bertujuan untuk meningkatkan, kepedulian, kemandirian, keberdayaan, dan kemitraan masyarakat tentang berbagai masalah yang berkaitan dengan lingkungan hidup. Keberhasilan beberapa kelurahan/desa meraih prestasi dalam pengelolaan lingkungan ditentukan salah satunya oleh kemitraan yang terbangun melalui komunikasi partisipatif di antara para pemangku kepentingan (aparat pemerintah dan pemerintah). Oleh karena 
itu, dengan kemitraan, maka kepedulian masyarakat terhadap masalah lingkungan akan tumbuh, permasalahan dana akan terjawab, dan kesejahteraan akan meningkat (Rahajeng \& Manaf, 2015).

Komunikasi partisipatif yang terjadi dalam pelaksanaan program Sabilulungan Bersih di Kabupaten Bandung, selain berlangsung secara dialogis, juga terbangun peningkatan kualitas dialognya, di mana pendapat yang disampaikan oleh peserta komunikasi yang beraneka ragam saling mengisi, dan kemudian menyatu. Pihak aparat menyampaikan informasi, kemudian diapresiasi oleh masyarakat dengan berbagai kepentingannya, kemudian terjadi dialog, setelah itu lahir kesepakatan, saling mendukung, dan kerjasama untuk melaksanakan program Sabilulungan Bersih sesuai dengan karakteristik lokal. Situasi dialogis dengan keterbukaan, memperjelas satu sama lain, sehingga melahirkan satu suara. Orientasi komunikasi dalam proses komunikasi yang berlangsung secara dialogis lebih dititikberatkan kepada "penyampaian pesan bersama orang lain", bukan sekedar "penyampaian pesan kepada", sehingga terjadi keseimbangan dalam transaksi komunikasinya dalam rangka memaknai suatu realitas (Lubis, 2018).

Faktor keterbukaan yang ditunjukkan dalam aktivitas komunikasi partisipatif pada saat melaksanakan program Saber menunjukkan
Praktik demokrasi pada tataran akar rumput yang menjunjung tinggi kedaulatan masyarakat untuk menyampaikan pendapatnya, dan sekaligus menerima pendapat pihak lain. Masyarakat diberi kesempatan seluas-luasnya untuk menyampaikan gagasan orisinalnya tentang permasalahan lingkungan, dan program yang akan dilaksanakannya, sehingga masyarakat bisa meninjau permasalahan dari berbagai sisi dan tidak tertutup terhadap masukan dari pihak lain. Keterbukaan merupakan salah satu karakteristik komunikasi yang efektif yang kualitasnya dapat dilihat dari saling terbuka dalam berkomunikasi, jujur dalam merespons komunikasi, dan bertanggung jawab terhadap apa yang disampaikannya (Devito, 2011).

Dari keterbukaan dalam berkomunikasi tersebut, lahirlah gagasan membuat program Saber versi wilayah masing-masing, seperti pembentukan Bank Sampah, Penataan Lingkungan Berbasis masyarakat Menuju Wilayah Green \& Clean, dan konservasi dengan menerapkan kegiatan yang disebut "pohon kelahiran”. Oleh karena itu, menginformasikan kebijakan pemerintah, menjembatani instansi dengan publik, dan menampung aspirasi publik menjadi kewajiban humas pemerintah (Kadarisman, 2021).

\section{SIMPULAN}

Aktivitas humas pemerintah dalam 
pelaksanaan kegiatan Sabilulungan Bersih di Kabupaten Bandung diartikan sebagai teknik komunikasi dalam menjalankan fungsi dan perannya, karena disampaikan bukan oleh bagian humas, tetapi oleh aparat yang berinteraksi langsung dengan masyarakat. Para aparat kecamatan dan kelurahan/desa berkomitmen dalam mendukung program Sabilulungan ini, karena harus mengamankan kebijakan atasannya (Bupati) di bidang penataan lingkungan hidup/persampahan sebagai salah satu koridor pembangunan di kabupaten Bandung. Komitmen ini memiliki pengaruh yang signifikan terhadap kinerjanya dalam mengimplementasikan program tersebut.

Mengabdi kepada kepentingan umum, dan memelihara komunikasi yang baik merupakan fungsi humas pemerintahan yang telah dipraktikkan secara intensif pada saat pelaksanaan kegiatan Sabilulungan Bersih dengan tujuan membangun pemahaman, dan kesadaran masyarakat, sehingga tercipta saling pengertian, kepercayaan, dukungan, kerja sama, toleransi, dan hubungan yang harmonis di antara kedua belah pihak. Oleh karena itu, fungsi humas pemerintah menjadi penting sebagai sarana untuk mengkomunikasikan berbagai rencana kerja, kinerja, dan pencapaian hasil yang dilakukan pemerintah kepada publik, serta merespons aspirasi publik, sehingga dengan komunikasi, kebijakan pemerintah dapat disosialisasikan, opini publik dapat disalurkan.

Peran humas dalam Praktik humas pemerintah pada saat pelaksanaan kegiatan Sabilulungan Bersih lebih kepada teknik komunikasi berupa diseminasi informasi, dan sebagai fasilitator komunikasi dengan menyediakan berbagai informasi yang terkait dengan pelaksanaan Saber, serta sebagai perantara komunikasi pemerintah dengan publiknya yang menunjukkan pentingnya interaktivitas pelayanan informasi oleh humas. Peran sebagai fasilitator juga melaksanakan pemantauan proses pelaksanaan pembangunan dan pendampingan kepada masyarakat, dan melakukan evaluasi program bersama masyarakat untuk bahan pelaporan kegiatan.

Peran sebagai teknisi komunikasi, dan sebagai fasilitator dalam pelaksanaan kegiatan Saber ini membantu masyarakat untuk dalam menyampaikan ide orisinalnya berdasarkan kapasitas, kapabilitas, dan sumber daya lingkungan yang akan dikelolanya sesuai dengan program yang akan dilaksanakan di wilayahnya. Komunikasi partisipatif yang terbangun dalam pelaksanaan kegiatan Sabilulungan Bersih dilakukan dalam sebuah forum pertemuan, dimana para pesertanya saling berinteraksi untuk bertukar informasi melalui dialog intensif dan berkesinambungan, yang dilandasi dengan keterbukaan dalam berkomunikasi untuk mencari solusi dalam 
mencapai kemajuan bersama dengan mengatasi berbagai hambatan, memperjelas satu sama lain, sehingga melahirkan satu suara. Keterbukaan yang ditunjukkan aparat kecamatan dan kelurahan/desa dalam aktivitas komunikasi partisipatif pada saat melaksanakan program Saber dengan masyarakat menunjukkan Praktik demokrasi pada tataran akar rumput yang menjunjung tinggi kedaulatan masyarakat untuk menyampaikan pendapatnya, dan sekaligus menerima pendapat pihak lain, sehingga dengan adanya keterbukaan sebagai salah satu karakteristik komunikasi yang efektif, maka muncul kejujuran dalam merespons komunikasi, dan bertanggung jawab terhadap apa yang disampaikannya.

Fungsi, peran humas pemerintah dalam pelaksanaan kegiatan Sabilulungan Bersih di Kabupaten Bandung pada dasarnya merupakan implementasi dari komunikasi partisipatif dalam rangka mengamankan salah satu koridor dari kebijakan pembangunan di Kabupaten Bandung, yaitu pembangunan di bidang lingkungan hidup. Untuk itu, sebagai rekomendasi bahwa komunikasi yang selama ini dilakukan aparat pada dasarnya merupakan Praktik humas pemerintahan yang mungkin saja tidak disadari oleh aparat tersebut. Oleh karena itu, para aparat khususnya kecamatan, dan kelurahan/desa perlu diberi pelatihan praktis tentang kehumasan, ketika berkomunikasi harus dilengkapi dengan pengetahuannya tentang lingkungan hidup, dilatih agar memiliki keahlian dalam mengelola media sosial, ditingkatkan kemampuannya berempati pada saat dialog berlangsung, sehingga keterbukaan komunikasi di antara kedua belah pihak menjadi tradisi demokratis yang permanen., objektif, dan terukur, sehingga bisa diterapkan di wilayah lainnya.

\section{DAFTAR PUSTAKA}

Agustin, W. A. (2017). Peran fasilitator dalam pemberdayaan masyarakat pada program penataan lingkungan permukiman berbasis komunitas. Jurnal Sosiologi DILEMA, 32(1), 69-78.

Ardianto, E. (2013). Handbook of public relations. Bandung: Simbiosa.

Cameron, W. dan. (2011). Dasar dasar public relations. Bandung: Remaja Rosda Karya.

Canfield, B. R. (2002). Public relations, principles:cases and problem. USA: Richard D. Irwin.

Cutlip, Scott M., Allen H. Center, G. M. B. (2009). Effective public relations (Tenth Edit). United State Of America: PrenticeHall.

Devito, J. (2011). Komunikasi antar manusia: kuliah dasar (ed. 5). Jakarta: Professional Books.

Dozier, Broom, G. and D. (2000). Using research in public relations. New Jersey: Englewood Cliffs. NJ. Prentice Hall.

Hadiyanto. (2008). Komunikasi pembangunan partisipatif: sebuah pengenalan awal.Jurnal Komunikasi Pembangunan, 6(2), 246359. https://doi.org/10.29244/jurnalkmp.6.2.\%p Hayati, N. (2017). Kemitraan sebagai strategi pemberdayaan masyarakat dalam program 
csr batik cap pewarna alami di pt. semen gresik pabrik Tuban. Sosiologi USK, 11(1), 43-50.

Idris, I. K. (2015). Peran humas pemerintah di era keterbukaan informasi (analisis isi permenpan-rb no. 6 tahun 2014 tentang jabatan fungsional pranata humas dan angka kreditnya). Jurnal Universitas Paramadina, 11(3), 1146-1163.

Ishak, A. (2012). Peran public relations dalam komunikasi organisasi. Jurnal ASPIKOM, 1(4), 373. https://doi.org/10.24329/ aspikom.v1i4.38

Iwank, W. (2019). Masalah sampah di kab/upaten bandunghttps://forkowas. com/2019/12/08/masalah-sampah-dikabupaten-bandung-bukan-persoalanbaru/.

Kadarisman, A. (2021). Government public relations dalam pengembangan pariwisata masa pandemi COVID-19 di Geopark Ciletuh. PRofesi Humas, 5(2), 270-290. https://doi.org/10.24198/prh.v5i2.29800

Kasmirus, W. (2013). Wiji kasmirus, peran kehumasan dalam membangun citra pemerintah. Jurnal Administrasi Reform, 1(1), 190-208.

Lee M. Neeley, G., A. S. K. (2012). The practise of government public relations. London: CRC Press.

Lubis, S. (2018). Komunikasi dialogis landasan masyarakat. CommuniquE, I(1), 1-6.

Modecai Lee, Grant Neeley, K. S. (2012). The practise of government public relations $(\mathrm{E}$. M. Berman, Ed.). New York: CRC Press.

Muchtar, K. (2016). Penerapan komunikasi partisipatid pada pembangunan di Indonesia. Makna, 1(1), 20-32. Retrieved from https://ejournal.bsi.ac.id/ejurnal/ index.php/cakrawala/article/view/2585

Muchtar, K. (2016). Penerapan komunikasi partisipatif pada pembangunan di Indonesia. Makna, 1(1), 20-32.

Multi, S. W., Syam, S., Usman, U., \& Fransiska, A. (2019). Fungsi humas dalam menjalin hubungan di pemerintahan Kota Bukittinggi. AL MUNIR: Jurnal Komunikasi Dan Penyiaran Islam, 2(2), 96-105. https://doi.org/10.15548/amj-kpi. v2i2.495

Newsom, \& Turk. (2009). This is pr: the realities of public relations. New York: Wadsworth Publishing Company, An International Thomson Publishing Company.

Putri, N. E., Hakim, N., \& Yamin, M. (2016). Ecologicall footprint and biocapacity analysis for flooding prevention in South Sumatera. Jurnal Mimbar, 32(1), 58-64.

Rahajeng, M. S., \& Manaf, A. (2015). Bentukbentuk kemitraan pemerintah, swasta dan masyarakat dalam upaya keberlanjutan ProgtramPenataanLingkunganPemukiman Berbasis komunitas (studi kasus: kabupaten Kendal dan Kota Pekalongan). Jurnal Pengembangan Kota, 3(2), 112-119.

Rahim, S. (2004). Participatory development communication as a dialogical process dalam White, SA. 2004. Participatory Communication Working for Change and Development. New Delhi: Sage Publication India Pvt Ltd.

Ruslan, R. (2014). Manajemen humas dan media komunikasi. Jakarta: Rajawali Press.

Salwa, A., Away, Y., \& Tabrani, M. (2018). Pengaruh komitmen, integritas, dan ompetensi terhadap kinerja pegawai serta dampaknya pada kinerja komisi independen pemilihan (KIP) Aceh. Jurnal Manajemen Dan Bisnis, 2(1), 58-67.

Sani, A. (2014). Optimalisasi fungsi humas pemerintah the optimization of government public relations. Edutech, 1(1), 78-106. 
Sari, P. P., \& Basit, L. (2018). Terhadap pembangunan Desa. Interaksi, 2(1), 47-60.

Servaes, J. (2002). Communication for development approaches of some governmental and non-governmental agencies. Paris: UNESCO.

Siswanto, B. D. L., \& Abraham, F. Z. (2016b). Peran humas pemerintah sebagai fasilitator komunikasi pada biro humas Pemprov Kalimantan Selatan. Jurnal Penelitian Komunikasi, 19(1), 55-68. https://doi. org/10.20422/jpk.v19i1.64

Suparna, P., Rachmawati, T. S., \& Winoto, Y. (2013). Keterbukaan komunikasi dalam menciptakan iklim komunikasi yang kondusif di perpustakaan. Jurnal Kajian Informasi Dan Perpustakaan, 1(2), 157-164. https://doi.org/10.24198/jkip. v1i2.11006

Sutowo, I. R. (2020). Komunikasi partisipatif dalam pengembangan kewirausahaan sosial di pandeglang, banten. Expose: Jurnal Ilmu Komunikasi, 3(1), 21. https:// doi.org/10.33021/exp.v3i1.885
Syarah, M. M., Rahmawati, M., Akademi, ), Bsi, K., Jalan, J., Jati, K. (2017). Komunikasi partisipatori pada program pemberdayaan masyarakat dalam penanganan tb. Cakrawala - Jurnal Humaniora, XVII(2), 250-257. Retrieved from https://ejournal. bsi.ac.id/ejurnal/index.php/cakrawala/ article/view/2585

Tasrin, K. dan S. A. (2014). Evaluasi kinerja pelayanan persampahan di wilayah metropolitan Bandung Raya (Performance Evaluation of Waste Management in the Greater Bandung Metropolitan Area). Jurnal Borneo Administrator, 10(1), 3558. https://doi.org/10.24258/jba.v10i1.163

Tubbs, Stewart \& Moss. (2008). Human communication: prinsip-prinsip dasar. Bandung: Remaja Rosdakarya.

Wahyono, E. (2018). Komunikasi kelompok: studi dialog komunitas dalam pengembangan masyarakat di perkotaan. Nyimak (Journal of Communication), 2(2), 113-130. https://doi.org/10.31000/nyimak. v2i2.961 